Article

\title{
Knocking on a Saint's Door, or a Quest for Holiness in a Post-Secular Society
}

\author{
Natalia Naydenova * and Yulia Ebzeeva \\ Philological Department, Peoples' Friendship University of Russia, 10 Miklukho-Maklay Street, \\ Moscow 117198, Russia; julia_eb@list.ru \\ * Correspondence: nns1306@mail.ru \\ Academic Editor: John A Jillions \\ Received: 23 March 2017; Accepted: 3 May 2017; Published: 17 May 2017
}

\begin{abstract}
The article examines Successors (Nasledniki, 2015) directed by Vladimir Khotinenko, illustrating a recent trend in the Russian film-making industry, namely, a rising interest in religious topics. While the Orthodox faith is widely seen by Russian political leaders as a basic aspect of national identity, the Church is also becoming more and more visible in the life of society, with religious holidays and events now receiving a higher profile in the public domain. The article analyzes how these trends shape the public consciousness and are reflected in the cinema production of recent years. Successors, a one location movie focusing on the debate over the role of Saint Sergius of Radonezh in the history of Russia, demonstrates that this 14th-century monk is very much present in the lives and minds of people 700 years later. In turn, this suggests that, under a layer of cynicism and consumerism, there is a growing hunger for holiness in a post-secular society.
\end{abstract}

Keywords: religious cinema; Russian cinema; Russian Orthodox Church; post-secular society; Saint Sergius of Radonezh; Khotinenko

\section{Introduction}

"It is not at all fortuitous that today's society is called post-secular", said the Patriarch of Moscow and All Rus, Kirill, in an interview (Patriarch of Moscow and All Russia Kirill 2009). The term 'post-secular', popularized by Jürgen Habermas, is used to describe a society where "religion maintains a public influence and relevance, while the secularistic certainty that religion will disappear worldwide in the course of modernization is losing ground" (Habermas 2008, p. 21). After 70 years of official atheism, Russia has experienced "a change in consciousness" (Habermas 2008, p. 20), with the resurgence of the Orthodox Church at the end of the 20th century. With civil components of the national identity providing little of sustenance (Sinelina 2013, p. 14), it is religious and ethnic aspects that have come to the forefront. Today's proliferation of religious discourses, on a national level in connection with value-laden civil issues and controversies (Habermas 2008, p. 20), suggests not only an intense public interest in religion, but also a belief that it can help in providing a more secure sense of collective and individual national identities (Rousselet and Agadjanian 2010).

In January 2016, the Synaxis of the Primates of the Orthodox Churches in Geneva adopted the draft document, entitled The Mission of the Orthodox Church in Today's World, wherein clause 13 expresses major concern over a growing "secularization in the face of a spiritual crisis", hence "a pressing need to highlight the importance of holiness" (Synaxis of the Primates of the Orthodox Churches 2016, p. 36). In the contemporary mediated world, these are first and foremost media texts that reflect, reinforce and shape systems of beliefs (Silverblatt et al. 2015, p. 3). Films remain a significant medium for the circulation of discourses in the Foucauldian sense; namely, in producing meaning and forming the objects of which they speak (Foucault 1972, p. 54). In this regard, as Joseph Kickasola puts it, 
"deploying and engaging with religious tropes is certainly not the same as assent to their foundational meanings, but it does imply a dialogue with those traditions, at the very least" (Kickasola 2016).

As Costica Bradatan points out, the relationship between cinema and religion is not only of a 'representational' nature, such that film becomes more than a mere vehicle for religious topics, notions, or symbols 'illustrating' them in a mechanical fashion. Beyond this, as Bradatan goes on, "Films and religion share a set of more fundamental, ontological suppositions" in that, "from its inception, film became intrinsically linked to the sacred" (Bradatan 2014, p. 2). Suffice it to remember André Bazin's pacte de croyance between the film and the viewer (Bazin 1975, p. 372). S. Brent Plate goes even further, drawing structural parallels between the altar and the screen (Plate 2008, p. vii). The latter comparison is reminiscent of the ideological mechanism of the Soviet atheist campaign, where cinemas were housed in former church buildings and elements of religious discourse were appropriated and re-invented to promote new values. Nikolay Berdyaev, in fact, recognized that "Communism [ ... ] wants to be a religion itself, to take the place of Christianity. It professes to answer the religious questions of the human soul and to give a meaning to life" (Berdyaev 1960, p. 158). Cinema was certainly the most efficient propaganda mechanism in the heyday of anti-religious campaigns in the USSR. Likewise, the enhancement of the Russian Orthodox Church's position in the late 2000s triggered a growing number of feature films with a religious component, such as The Island (Ostrov, 2006) by Pavel Lungin, focusing on repentance, The Priest (Pop, 2009) by Vladimir Khotinenko, about the Church during the Second World War, and Andrey Zvyagintsev's controversial Leviathan (Leviafan, 2014).

Religious motifs were also found in TV series and cartoons. Thus, the events of the action mini-series, Save Yourself, Brother (Spasajsja, Brat, 2015), take place in a monastery. The Wonderworker (Chudotvorica), a television show consisting of 12 episodes, also released in 2015, is based on the hagiography of Saint Matrona of Moscow, one of the most popular Orthodox saints of the 20th century. Serafima's Extraordinary Journey (Neobyknovennoe Puteshestvie Serafimy, 2015), the first animated fantasy promoting Orthodox ideas through an adventure story, attracted a large audience. It tells the story of an 11-year-old girl, a daughter of a priest executed during the great terror of the 1930s. Supported by her patron saint, Serafima manages to overcome all hardships, maintains her faith and at last is reunited with her mother. Finally, the recent success of Kirill Serebrennikov's The Disciple (Uchenik) at Cannes 2016, featuring the story of a student obsessed with religion, shows that, to paraphrase Bazin, 'the cinema is still interested in God" (Bazin 2002, p. 61).

Moreover, beyond the cinema, state authorities, in the face of the threat of disintegration, have placed their own faith in religious holidays and events. This is the case, with the public holiday known as the National Unity Day, which takes place on 4 November. It was reinstated in 2005 to replace the 'Day of the Great October Socialist Revolution', celebrated under the Communist regime on 7 November. The National Unity Day commemorates the popular uprising which expelled Polish occupation forces from Moscow in 1612, thus ending the Time of Troubles, and also coincides with the feast day of Russia's most famous icon-Our Lady of Kazan.

Another recent example, dating back to 2014, is the commemoration of the 700th anniversary of Saint Sergius of Radonezh, the founder of Russian spiritual mysticism in the 14th century. He is also considered to be the peace-maker who united the feuding Russian princes, thus laying the foundations of uniting the Russian lands under the leadership of Moscow. The celebrations were financed by the Ministry of Culture at a cost of 6.5 billion roubles (Ministry of Culture of the Russian Federation 2014). On 17 July 2014, Patriarch Kirill delivered a speech at the Holy Trinity-Saint Sergius Lavra, the most important Russian monastery, situated in Sergiev Posad, claiming that holiness has always been intrinsic to "the Russian national idea" (Patriarch of Moscow and All Russia Kirill 2014, pp. 17-18). His speech was followed by Vladimir Putin's address to the heads of the delegations of the Orthodox Churches, where the President expressed his hope for their "moral and spiritual support in promoting the values we serve together" (Patriarch of Moscow and All Russia Kirill 2014, p. 19). The events commemorating the anniversary of one of the most venerated Russian saints included exhibitions, 
and, most importantly, television programs and films. The latter includes Successors, a feature film that will be the focus of the rest of this article.

\section{A Room with a Saint}

Successors was produced and directed by Vladimir Khotinenko, a famous Russian director known for such films as A Moslem (Musulmanin, 1995), 72 Metres (72 Metra, 2003), and The Priest (Pop, 2009). The film did not have a robust budget. Therefore, the shooting lasted only 19 days. What strikes one first about the film is the originality of its setting: the events take place in a TV studio, where a talk show is being filmed. We can recall only two examples of the one location movies in the Soviet cinema: Bonus (Premija, 1974) by Sergey Mikaelyan and Garage (Garazh, 1979) by Eldar Ryazanov. As the journalist Dmitry Anokhin states, both films became classics of the Russian cinema a long time ago (Anokhin 2015, p. 76). As for the most recent period in the country's history, the only example, prior to Khotinenko's Successors, was Nikita Mikhalkov's 12 (2007). It should be remembered that Khotinenko hosted a talk show on Russian TV, which might have helped him. However, the director of 25 films confesses that Successors is "the most capricious and least predictable of his children". He does not expect the message of the film to reach society as a whole but to touch the souls of people individually. As he puts it, "If something moves in the spectator's soul, I can consider my objective achieved" (Anokhin 2015, p. 76).

The events of Successors take place in the summer of 2014, in a studio, where a talk show hosted by Gleb Tregubov is being filmed. Six guests have been invited to share their opinions on Saint Sergius: a successful political expert affiliated with the government authorities, German Zvonarevsky (played by actor Anatoly Bely), his former classmate and also now a professional historian, Dmitry Osipov (Alexander Korotkov), a former colonel and a neophyte politician, Vladimir Skvortsov nicknamed the 'patriot' (Alexander Baluev), a famous pop singer, Angelina Nevedina (Agrippina Steklova), a monk of Saint Sergius Lavra Father Cyprian (Sergey Kachanov) and, finally, a pediatrician from Sergiev Posad Ekaterina Kuznetsova (Alla Yuganova). They are not just seen through the eyes of the audience but also through the eyes of the technical staff of the talk show: we thus see images transmitted from the multi-camera setup, from studio monitors on the director's desk, and on the general producer's laptop. The spectator is also given a sneak view of how the show is prepared: a crowd of extras at the entrance are instructed to switch off their cell phones and, at the assistant's signal, to rehearse their applause. Among the extras there are two young men, Pasha and Stas, who use the talk show as an alibi after having taken part in the brutal beating of a migrant from Central Asia. Stas is one of the attackers while Pasha is the head of the gang.

The speakers' opinions on Saint Sergius and his role in the history of Russia reflect the current debate over national identity and the current situation in Ukraine. The saint is seen as having a variety of roles: as a humble monk, a perspicacious politician, and even as a dissident. We see how history can be manipulated in support of one's own stance. Thus, for the politician, Saint Sergius is the one who stopped the feud among local princes and united the country, which is certainly in line with the official rhetoric of the State and the Church. He also suggests omitting or paraphrasing some parts of the saint's life to make it more suitable for promulgating his own message. In contrast, for the 'patriot', the saint embodies 'Holy Rus' as a transcendental concept of a unifying national force and inter-confessional dialogue based on common moral and spiritual values. Both of these opinions, though, are vigorously contested by the historian, who argues that the Russian nation barely existed in the times of Saint Sergius.

The format of the show is used to introduce catechetical elements, consisting first and foremost of a description of Saint Sergius' life turning the film to a certain extent into a 'catechism-in-pictures' (Bazin 2002). A detailed account of the saint's life is given in special introductory videos, which are set alongside flash interviews conducted in the street. According to Khotinenko, the passers-by who participated in the interviews were not aware of taking part in a feature film: "Initially, we wanted to 
make a documentary. It was only afterwards that we got an order from the Ministry of Culture and changed our plans" (Anokhin 2015, p. 75).

Apart from Baluev, the film does not boast the participation of any stars, but it does contain cameo appearances by real members of show-business; namely, Olga Shelest, Alexander Oleshko and Alexander Gordon. It is the latter who informs Gleb, in a friendly chat during the break, that the show is about to be closed. This makes him take the drastic decision to abandon the script and to start live streaming the talk show over the internet. When Gleb starts live streaming the show, he orders to fill the studio with thick smoke from a previous program about the Apocalypse.

The talk show resumes with a blunt question: "Isn't it time to recognize that the baptizing of Rus was a mistake, that this poisoned Byzantine root is at the origin of all our troubles?" This marks a turning point in the plot. The participants of the talk show accept the challenge and begin to show their true colors. In a private conversation with his former classmate, Zvonarevsky repents his preference for making easy money over conducting disinterested science. The doctor is unhappy in her marriage, while the historian has no family of his own and is involved in an endless quest for historical truth. The pop diva turns out not to be as silly and frivolous as she appears. Finally, the colonel, the so-called 'patriot', is taken away in an ambulance after having received a call from his son who is a drug addict.

Once the show finishes, Pasha wants Stas to follow him, but after talking to Father Cyprian the boy declines his offer. The gang leader pretends not to be offended at all. He gives Stas a hug, saying, "Don't forget me" and "It's OK-we'll settle up one day". However, at the very last moment, and when he least expects it, Pasha gives Stas a sneaky punch. When Stas falls on the ground, the gang leader spits on him. This scene constitutes a brief preview of the standoff with the evil the young man will have to face after the closing credits of the film.

However, the quintessence of the film is expressed in an eloquent scene that appears on the official poster of the film. It shows Father Cyprian sitting alone in the studio next to the dummy of a tyrannosaur, which has been prepared for the following night's show, World Without People. This grotesque episode can be interpreted in various ways. For example, the lonely figure of the monk could represent a silent witness to the apocalyptic times that the people will have to endure. Likewise, the monster could presage future powers equivalent to the tyrant from the Book of Revelation. Finally, the scene might allegorically suggest humanity's eventual self-extermination.

\section{Successors: A Family Portrait of Russian Society}

The talk show participants provide a vivid portrait of contemporary Russian society and the opinions that they voice are certainly those at the heart of today's debates. As Anokhin points out, the major question that arises for the spectator is how a shifty and ambitious political expert, a loser scientist, a silly pop diva, and an audience that applauds on command, can be the successors to a saint. The conversation during the talk show reveals the guests' disdain for contemporary Russian society, showing how easily manipulated and overfed the public are by the mass media, being capable of clichéd thinking only.

Paradoxically, the most enigmatic character in the film turns out to be the pop singer, who, at first glance, seems the most stereotypical and therefore predictable. Her superficial and banal comments during the first part of the show form a stark contrast with the thoughts she shares in private with the doctor, in the second part:

They keep arguing over why Sergius left [the monastery he founded]. I think it's like in a family: if you have it, there's no need to prove anything to anyone. And if not ... There's no point in it.

When astounded Ekaterina asks her to voice this opinion in public, Angelina refuses: "I haven't come here to say smart things. There are specially trained people for this purpose."

During the show, Angelina is more than once publicly ridiculed for her songs. However, when asked to sing, she performs arias from operas by Puccini and Borodin, demonstrating that she has the 
vigorous and beautiful voice of a professional, talented singer. Aside from this, she seems to be the only one who knows how to address a priest. At the beginning of the film, Gleb uses an erroneous term and is corrected by his assistant, who previously looked it up on the internet. When the colonel has a heart attack, it is Angelina who lets Father Cyprian in, saying: "Please, come in, batyushka" [diminutive for "Father," an affectionate term of respect for a priest].

The audience is given an insight into Angelina's character through a biblical allusion, used initially by the 'patriot', who exclaims that the showman is worse than the prima donna because "he knows what he is doing". Later, at the end of the talk show, this passage from Saint Luke (23:33-4) is echoed by Angelina when, with a defenseless smile, she declares that she does not know what she is doing. Although her words refer to a quite mundane situation (she cannot get back home because she has let her driver go), after everything the participants have been through during the show, they seem to have deeper implications. This is also alluded to in Angelina's last name-Nevedina-which literally means 'the one who does not know'.

The Church is represented in the film by Father Cyprian, who is the last-minute replacement for another clergyman. Unlike his colleague, whose absence is lamented by the talk show host, Father Cyprian is not experienced in appearing on TV. He looks at the surrounding environment with a mixture of curiosity, sorrow, and pain. He speaks little, and, when he does, his words sound simple and even naive.

When talking to the other talk show participants, Father Cyprian answers the list of most frequently asked questions of neophyte believers and refutes many of the current stereotypes held by people. For instance, when Angelina shares her excitement about fasting ("I adore fasting! Prawns, rocket salad"), the monk gently disagrees: "Why should you push yourself to such extremes? As an elder said, you can even eat meat, the main idea is not to eat each other." Father Cyprian speaks with subtle humor, avoiding any moralizing or preaching. At the same time, he does not pretend to have a monopoly on the truth. When Stas desperately asks him what to do about his family situation, Father Cyprian looks at him in sorrow and confesses, "I don't know".

Father Cyprian answers mundane queries with passages from religious texts. For instance, when the showman exclaims that Russians will soon be banned from visiting foreign countries, the monk quotes a sentence from the prayer composed by the elders of the Optina Monastery at the end of the 19th century: "Grant unto me, O Lord, that with peace of mind I may face all that this new day is to bring" (the translations of the prayers in this article are from http:/ / www.ocf.org.), adding: "There are no exceptions mentioned there about everyday hardships or not travelling abroad on holidays".

It should be noted that there seems to be no lay believer among the talk show guests, whereas, in the traditional Soviet propaganda, such figure was usually embodied by an old woman, an obscurant church goer, frequently, and pejoratively, called babka (old crone). At first glance, this typical character appears to be physically absent from Successors, but she turns out to be behind the scene. When the guests are asked to provide a word which they associate with Saint Sergius, the doctor says 'grandma' (babushka) provoking laughter among the audience. The laughter seems to arise because her response strikes them as irrelevant, bewildering the studio viewers. It is only towards the end of the film that the doctor tells them all that her grandmother secretly kept Saint Sergius' head when his relics were confiscated after the revolution of 1917. Thus, a gloomy, ignorant babka from Soviet propaganda turns into a kind babushka; that is, a keeper of family and even national, spiritual values.

If babushka represents one pole of moral values, though, Pasha represents the other, epitomizing a nonchalant, self-confident evil. His appearance speaks for itself: he is dressed almost entirely in black leather, with a T-shirt imprinted with a wolf baring his teeth—one of the Orthodox prayers to be read before the Holy Communion pleads for delivering from becoming "the prey of the wolf of souls", a metaphorical designation of evil thoughts—and on his iPhone screen he has a huge crown.

When speaking to his friends about Stas, Pasha says: "He's a normal guy. He's one of our kind. He's just a newbie, but that'll come with time. Okay, he'll have his baptism of fire tomorrow." Pasha's words might bring to mind those of Pyotr Verkhovensky, a revolutionary character from 
Dostoyevsky's Demons, where the chapter describing the meeting of an insurrectionist cell is titled Among our Own (Dostoyevsky 2008). It should also be mentioned that Khotinenko recently directed a mini-series on Dostoyevsky's Demons. The use of that possessive pronoun, 'our', suggests that Stas faces a dramatic choice: whether to maintain his independence or be manipulated by Pasha, who, like Verkhovensky, cements the bonds among his gang members by the "baptismal rite" of terrorizing and even murdering Asian migrants. In fact, Stas was wounded earlier in the day as a result of his involvement in the collective beating of a market seller. His resultant scar confronts him like a Christian stigmata, reminding him of the past he is about to reject, but which will cling to him tenaciously.

Successors does not simply mirror the most typical traits of contemporary Russian characters, but suggests that they are more complex and, most importantly, capable of change. The key message of the film is that conversion (metanoia in Orthodox ascetics) is an option open to everyone, although, as represented by the film's creators, it is only possible by engaging with Christianity. Philosopher and theologian Bernard Lonergan distinguishes three interrelated forms of conversion: intellectual, moral and religious. Intellectual conversion involves the discovery of a "truth attained by cognitional self-transcendence" (Lonergan 1973, pp. 239-40), whereas moral conversion requires "a change in the criterion of one's decisions and choices from satisfactions to values" (Lonergan 1973, p. 240). Both of these forms are 'sublated' by religious conversion, which involves the "fated acceptance of a vocation to holiness" (Lonergan 1973, p. 240).

This film draws most centrally on a narrative of moral conversion, which is securely underpinned by a religious moment. Thus Stas' change of heart is triggered by the words of Father Cyprian about Saint Sergius. Stas then confesses to the monk, "I wanted to kill [my father], but I listened to you and felt such an anguish". Therefore, it is implied that it is the synergy of the saint and his disciple that make the young man change the vector of his life. Stas' desire to kill his biological father, an alcoholic who beats his mother, is replaced by a longing to come closer to his Heavenly Father, albeit, it is recognized, this will not be an easy task. In the words of Saint Matthew (7: 13-14), Stas clearly chooses 'the narrow gate', as evidenced in his final exchange with Father Cyprian:

Stas: "I want to do it in a human way, like people do! If that one ... Sergius ... could do it ... it means that it is possible?"

Father Cyprian: "It is necessary. But it's not easy."

The issue of choice is also raised in connection with Gleb Tregubov, the show's presenter: "You seem to have made your choice today", the monk surprises him by asking, after the show is over. For, following his last appearance on air, Gleb intends to leave not only Moscow but show business itself. However, once he has made this decision, he is immediately tempted by his boss (who is also his lover). She offers him the chance of hosting a new, "anti-corruption" talk show. It remains unclear what he will choose, but the banner in the final episode, advertising the new TV show, contains the words, "It's up to you!" When asked about the highlights of the open finale, Khotinenko says: "For me, it's [Stas'] smile. It's the process that started in his soul. Let God grant it to all of us ... " (Anokhin 2015, p. 76).

\section{A Long Path to Metanoia}

In Russian culture, Saint Sergius is represented as dynamic and versatile, opening up an endless road to the future. The description of his life contains numerous examples of his pilgrimages across Russia, during which he founded monasteries and acquired new disciples. One of the talk show participants picks up on this, saying, "Father Superior walked across the vast Russian land on his own feet". Historian Vasily Klyuchevsky noted that the spiritual influence of Saint Sergius "outlasted his earthly life and transformed his name ... into an eternally active moral engine" (Klyuchevsky 2014, p. 78-translation from http://russia-ic.com/people/Historical_Figures\%20//757). This notion of Saint Sergius as a human dynamo runs like a thread through the film, invisibly connecting him to his successors. 
It is surely significant, then, that the opening theme of the talk show features a train travelling through history. "Everyone has his own path: from a person to a nation as a whole", declares the monk at one point in the show. The climax of the film is reached when Ekaterina tells the family story about the rescue of Saint Sergius' head after his relics were desecrated by the Bolsheviks. The doctor, in turn, speaks over the background noise of the train. Her story grabs the audience's attention. It is based on real events and features Father Pavel Florensky, a famous mathematician and theologian, who rescued the saint's head, and Father Pavel Golubtsov, who took it out of the monastery to its new hiding place. Yet again, the monologue about the saint's relics is driven by the idea of permanent movement. Father Pavel Golubtsov carried the saint's head along the Kazanskaya railroad for a long time. Ekaterina emphasizes that even when the priest was on the train, he never sat down, nor did he put the precious thing he carried on the seat, owing to his veneration of the sacred relics. He kept walking back and forth through the train cars for the entire trip:

You see, nobody watched him. And even had he sat down, I'm sure no one would have reproached him. Sometimes I ask myself: and I, do I have anything in my life for the sake of which I would walk like this? Something I would keep like this? Be ready to give my life for? Well, family ... but ... something else?

This passage homes in on one of the key questions raised by the creators of the film. For there seems to be an unconscious desire amongst modern people to find something beyond the mundane happiness and values celebrated by today's "society of consumption". As Gleb declares bitterly, after hearing the story of Pavel Florensky's refusal to leave Russia and his voluntary martyrdom for the Orthodox faith: "I don't understand what is so bad about saving your life?! Bring up your children, go abroad, start from scratch? Why do you always have to go to extremes?" This rhetorical question already contains the answer, as a response Gleb makes elsewhere-“Just to live well."-is shown to be an inadequate basis for a fulfilled life. A comfortable lifestyle, however much it is advertised as the ideal, leaves people empty in the long run. There is always the hunger of the soul for something beyond.

This idea is crystallized in the closing scene of the film, which shows a message written on a bridge wall, signed by someone nicknamed 'Wizard': "This is the clue-it is the future of postmodernism. I invented you". This graffito, along with its spelling mistakes, almost literally constitutes the "writing on the wall', being a warning to postmodern society, where the souls of those seduced by simulacra are endlessly reinvented by some invisible 'wizard', obscuring the real values by the smokescreen of relentless consumerist propaganda.

At the end of the film, Stas is shown leaving his gloomy residential area and crossing the bridge along the railroad. In the background, as the wheels of the train sound, he leaves behind the walls defaced by graffiti, looks at the new district of Moscow, called Moskva-City, with its skyscrapers, then pauses for a while before noticing a billboard announcing Gleb Tregubov's new talk show. The show is called Emergency Brake and its slogan is: "Stop! I'm getting off". This closing episode encapsulates the main idea of the film: that is, it is never too late to pull the handle of the emergency brake and embark upon a new path.

The choice evoked in the film - between truth and lie, good and evil—can best be captured in Dostoyevsky's famous quotation about the field of life: that "God and the devil are fighting there and the battlefield is the heart of man" (Dostoyevsky 1929, p. 130). Thus the doctor asks, "What does good mean for you?", while evoking the professional burnout experienced by her colleague working at a hospice. To which Father Cyprian's words might provide a suitable reply: "Maybe Saint Sergius' story is about making your choice ... between the truth for me, the truth for the people and the truth for God". 


\section{Conclusions}

When reflecting on Saint John Chrysostom's homily on Acts, Father John Jillions says that "we are safest when in the company of the saints". Saint John Chrysostom does not mean the saints of ancient days. He urges his listeners to seek out the holy people of today, visiting them and inviting them into our homes. Thus they will absorb how to be peaceful and safe even in the midst of storms (Jillions 2015).

In the 21st century, characterized by the atomization of society and the evident helplessness of individuals in the face of globalization, people seem to be more desperate to connect with the metaphysical side of life; that is, somewhere that they try to find responses to the questions which cannot be answered from a materialistic point of view. Father Cyprian tries to capture this insight when he states: "What is important about Sergius is that he existed. And most importantly that he is with us now. He is above time".

The reception of the film by the critics was predominantly positive. It was called a litmus paper, a portrait, or even a diagnosis of the Russian society (Vasilieva 2015; Anisimova 2015; Kolensky 2015). The reviewers were almost unanimous in praising the narrative structure of the film, compared to Bakhtin's polyphony, which allowed "to tell the story full of gaps, contradictions, different interpretations of the same events" (Zabaluev 2015; Ostashevsky 2015). But among this multitude of voices it is the quiet voice of Saint Sergius that sounds loud symbolizing 'miracle and hope' for the film creator: "He could stand between the most implacable enemies and peacefully speak about the soul" (Ostashevsky 2015).

Successors is not the only Russian film featuring a saint as the key character. In Serafima's Extraordinary Journey, an animated film mentioned at the beginning of this article, Saint Serafim plays a crucial role. He is Serafima's friend, whose intercession helps her become reunited with her family, both spiritually and physically. It is easy for Serafima, a child "pure at heart" (Matthew 5:8), to take the saint by the hand and trustingly follow him. For a grown-up person living in the contemporary world, full of "the lust of the flesh, the lust of the eyes, and the pride of life" (John 2:15-17), it is a lot more difficult, if not nigh on impossible. Therefore, Saint Sergius, also being one of the characters of the film, is invisibly present in the studio, giving answers to the desperate questions emanating from people's souls, although not everyone is yet ready to understand them or, most importantly, to accept them.

Author Contributions: The research was designed by Natalia Naydenova. The analysis was carried out by Natalia Naydenova and Yulia Ebzeeva and they wrote the paper together.

Conflicts of Interest: The authors declare no conflict of interest.

\section{References}

Anisimova, Lyudmila. 2015. Fil'm Khotinenko “Nasledniki”-Portret sovremennoj Rossii. October 5. Available online: http:/ / press.lv/post/film-hotinenko-nasledniki-portret-sovremennoj-rossii/ (accessed on 8 March 2017). Anokhin, Dmitry. 2015. Zerkalo dlja kameo. Zhurnal Moskovskoj Patriarhii 11: 74-76.

Bazin, André. 1975. Qu'est-ce que le cinéma. Paris: Cerf.

Bazin, André. 2002. Cinema and Theology: The Case of Heaven over the Marshes. Journal of Religion and Film 2: 15. Available online: http:/ / digitalcommons.unomaha.edu/cgi/viewcontent.cgi?article=1763\&context=jrf (accessed on 8 March 2017).

Berdyaev, Nikolay. 1960. The Origin of Russian Communism. Ann Arbor: University of Michigan Press.

Bradatan, Costica. 2014. Introduction: Dealing (Visibly) in Things not Seen. In Religion in Contemporary European Cinema: The Postsecular Constellation. Edited by Costica Bradatan and Camil Ungureanu. New York: Routledge, pp. 1-10.

Dostoyevsky, Fyodor. 1929. The Brothers Karamazov. Translated by Constance Garnett. New York: Modern Library. Dostoyevsky, Fyodor. 2008. Demons. Translated by Robert A. Maguire. London: Penguin Classics.

Foucault, Michel. 1972. The Archaeology of Knowledge. New York: Pantheon Books. 
Habermas, Jurgen. 2008. Notes on Post-Secular Society. New Perspectives Quarterly 25: 17-29. [CrossRef]

Jillions, John A. 2015. Acts 27:1-44 Safe in the Company of the Saints. June 23. Available online: https:/ /oca.org/ reflections/fr.-john-jillions/june-23--2015 (accessed on 8 March 2017).

Kickasola, Joseph. 2016. Tracking the Fallen Apple: Ineffability, Religious Tropes, and Existential Despair in Nuri Bilge Ceylan's Once Upon a Time in Anatolia. Journal of Religion E Film 20: 13. Available online: http:/ /digitalcommons.unomaha.edu/jrf/vol20/iss1/13 (accessed on 8 March 2017).

Klyuchevsky, Vasily. 2014. Znachenie Prepodobnogo Sergija Radonezhskogo dlja russkogo naroda i gosudarstva. Razvitie Lichnosti 4: 60-80.

Kolensky, Alexey. 2015. Vladimir Khotinenko: “Ne ozhidal, chto televizionshhikam moja kartina pokazhetsja obidnoj". October 27. Available online: http://portal-kultura.ru/articles/person/123811vladimir-khotinenko-ne-ozhidal-chto-televizionshchikam-moya-kartina-pokazhetsya-obidnoy/ (accessed on 8 March 2017).

Lonergan, Bernard. 1973. Method in Theology. New York: Herder and Herder.

Ministry of Culture of the Russian Federation. 2014. Rossija gotovitsja otprazdnovat' 700-letie so dnja rozhdenija prepodobnogo Sergija Radonezhskogo. April 30. Available online: http://mkrf.ru/press-center/news/ ministerstvo/rossiya-gotovitsya-otprazdnovat-700-letie-so-dnya-rozhdeniya-prepodobnogo-sergiya (accessed on 8 March 2017).

Ostashevsky, Dmitry. 2015. Recenzija: “Nasledniki" Vladimira Khotinenko. June 29. Available online: http: / / thr.ru/cinema/recenzia-nasledniki-vladimira-hotinenko/ (accessed on 8 March 2017).

Patriarch of Moscow and All Russia Kirill. 2009. Cerkovnaja zhizn' dolzhna byt' sluzheniem. Izvestija. Available online: http:/ /izvestia.ru/news/348393 (accessed on 8 March 2017).

Patriarch of Moscow and All Russia Kirill. 2014. Igumen zemli Russkoj. Zhurnal Moskovskoj Patriarhii 8: 14-19.

Plate, S. Brent. 2008. Religion and Film. Cinema and the Re-creation of the World. London: Wallflower.

Rousselet, Kathy, and Alexander Agadjanian. 2010. Individual and Collective Identities in Russian Orthodoxy. In Eastern Christians in Anthropological Perspective. Edited by Chris Hann and Hermann Goltz. Oakland: University of California Press, pp. 265-79.

Silverblatt, Art, Jane Ferry, and Barbara Finan. 2015. Approaches to Media Literacy: A Handbook. London: New York: Routledge.

Sinelina, Yulia. 2013. Religija v sovremennom mire. Expert 1: 14-20.

Synaxis of the Primates of the Orthodox Churches. 2016. Missija Pravoslavnoj Cerkvi v sovremennom mire. Zhurnal Moskovskoj Patriarhii 4: 31-36.

Vasilieva, Yulia. 2015. Vladimir Khotinenko: “Nasledniki-lakmusovaja bumazhka Rossii.”. December 2. Available online: http://sobesednik.ru/kultura-i-tv/20151202-vladimir-hotinenko-naslednikilakmusovaya-bumazhka-rossii (accessed on 8 March 2017).

Zabaluev, Yaroslav. 2015. Dym russkogo apokalipsisa. June 25. Available online: https://www.gazeta.ru/culture/ 2015/06/25/a_6854185.shtml (accessed on 8 March 2017).

(C) 2017 by the authors. Licensee MDPI, Basel, Switzerland. This article is an open access article distributed under the terms and conditions of the Creative Commons Attribution (CC BY) license (http://creativecommons.org/licenses/by/4.0/). 